\title{
Juynboll, al-Zuhrī, and al-Kitāb: About the Historicity of Transmission below the Common Link Level
}

\author{
Pavel Pavlovitch
}

\section{Introduction}

In several of his publications, Gautier H.A. Juynboll argued that short legal maxims as well as entertaining and uplifting narrations (qașaș) by first-century storytellers (qāṣs, pl. quṣṣāṣ) might pre-date by a generation or two the common link $(\mathrm{CL})^{1}$ in an isnād bundle. ${ }^{2}$ Apart from that, Juynboll doubted the possibility of dating traditions before the $\mathrm{CL}$; in fact, he regarded many apparent CLs as, at best, "the conceivable, often even more or less historically tenable, originators of a tradition under scrutiny."3 Juynboll's mistrust of the CL and the CL's alleged sources was driven by his focus on isnād analysis as the key to answering the questions of "where, when and at the hands of whom a certain tradition originated." 4 This is not to say that Juynboll disregarded the substantive content of hadith, known as its matn (pl. mutūn). ${ }^{5}$ Nonetheless, his

1 The CL is the earliest historically ascertainable transmitter at the point of convergence of several lines of transmission (isnād, pl. asānìd) carrying similar or identical contents (mutūn). By contrast, the term "key figure" denotes a point of convergence that may be either a historical or a seeming CL. Modern hadith scholars have interpreted the CL phenomenon in various ways (see Andreas Görke, "Eschatology, History, and the Common Link: A Study in Methodology," in Method and Theory in the Study of Islamic Origins, ed. Herbert Berg (Leiden: Brill, 2003), 188-191).

2 Gautier H.A. Juynboll, "Some Notes on Islam's First Fuqahä’ Distilled from Early Hadịt Literature," Arabica 39, no. 3 (1992): 302-309; Gautier H.A. Juynboll, "Early Islamic Society as Reflected in Its Use of Isnäds," Le Museon 107 (1994): 16o-171. About the meaning of the term "isnäd bundle," see note 5 below.

3 Gautier H.A. Juynboll, Encyclopedia of Canonical Hadith (Leiden: Brill, 2007), xx; cf. Gautier H.A. Juynboll, "Nāfic, the mawlā of Ibn 'Umar, and his position in Muslim Hadìth Literature," Der Islam 70, no. 2 (1993): 216. The reason for this negative stance is Juynboll's presumption that single-strand asānīd above the key figures are useless for buttressing their status as CLS ("Nāfi'," 211-216). Juynboll's dismissal of the single strands came in response to Michael Cook's criticism of isnād analysis ("Nāfi'," 213 and Cook's work cited thereto).

4 Juynboll, "Nāfi', 207; cf. Juynboll, 209.

5 Thus, Juynboll distinguished between the "protoversion of the matn," put into circulation by 
reliance on al-Mizzī's Tuhfat al-ashräf bi-ma'rifat al-aträf (A Gift to the Exalted in the Knowledge of Epitomes), which comprises traditions as epitomised by their most salient parts (taraf, pl. aträf), blunted his attentiveness to textual details. Juynboll's generalizing approach to the matn substance stands out conspicuously in his treatment of the collective asānìd in which a single transmitter alleges to have received variants of early qașaș from several informants, without providing details about the degree of overlapping between their formulations. Thus, while drawing attention to the variation of motifs in several versions of the 'A'isha slander narrative (hadith al-ifk) ${ }^{6}$ on the authority of alZuhrī (d. 124/742), ${ }^{7}$ Juynboll averred, "the wording of the ifk story is doubtless Zuhri's." ${ }^{\prime}$ In this manner he set aside his inveterate scepticism with respect to the CL and the single-strand isnäd. What is more, he went on to accredit the transmission of al-Zuhri's four purported informants, without thoroughly addressing the possibility of at least some of them being an unhistorical transmitter or inventor of the narrative. ${ }^{9}$

In this essay, I will attempt to show that apart from the general meaning, or the "gist" of traditions, scrutinizing textual details, even the minutest ones, may

the CL, and its later modifications by the various partial CLs ("Nāf'," 212; cf. "Early Society,"

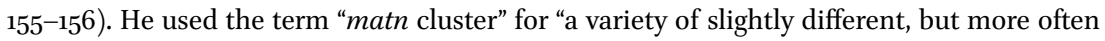
than not closely resembling, if not wholly identical, matns" ("Nāfi', 224-225; cf. Juynboll, "Early Society," 178, note 70; Gautier H.A. Juynboll, "Muslim b. al-Hadjdjādj," in Encyclopaedia of Islam, 2nd ed., accessed 13 August 2018, http://dx.doi.org/10.1163/1573-3912_islam_SIM -5597), and, when speaking of a "bundle," he meant a group of asānìd carrying "one and the same text" ("Nāfic," 209). Juynboll applied these principles in his study of the first-revelation narrative, in which he distinguished between the $m \bar{a}$ aqra'u ("What should I read?" or "I cannot read") version, put into circulation by 'Ubayd b. 'Umayr (d. 68/687), and al-Zuhrìs (d. 124/742) grammatically streamlined formulation, mā anā bi-qāri"in ("I am not one who reads") ("Early Society," 16o-166).

6 During one of the Prophet's raids, 'Ā'isha reportedly got lost in the desert and was picked up by a straggler, whereupon detractors accused her of being unfaithful to the Prophet (for details, see Gregor Schoeler, Charakter und Authentie der muslimischen Überlieferung über das Leben Mohammeds (Berlin: Walter De Gruyter, 1996), 119ff.).

7 Juynboll, "Early Society," 183-185.

8 Juynboll, 181.

9 Juynboll, 181-182. In his reflections on Șayf b. 'Umar's (d. c. 173-193/786-8o9) asānìd, Juynboll is somewhat more reserved. According to him, Sayf's collective asānìd, "more likely than not, yield genuine data transmitted by his authorities," whereas his single strands, "are often (not always) of his own making" ("Early Society," 189). The problem here lies in Juynboll's presumption that Șayf's collective asānīd are genuine not in their own right, but because the collective asānìd in the transmissions of al-Zuhrī and Ibn Isḥāq are so ("Early Society," 189-19o). Even if the latter assertion may be argued for, on a form-critical basis, with regard to hadith al-ifk, it is nevertheless epistemologically disadvantageous to treat an individual case as a universal paradigm that applies to most collective asānìd conveying qașaș material. 
contribute significantly to the reconstruction of the matn at the various stages of its textual evolution. I will argue that by applying form-critical approaches, we may indeed be able to trace the history of a tradition and its constituent motifs below the CL level, that is, navigate our path into the murky domain of the single-strand asānid. To that end, I will study the statement of the famous hadith collector Ibn Shihāb al-Zuhrī that Umayyad amirs forced him, along with other traditionists, to write down Tradition (kitāb al-ilm), despite their aversion to writing, whereupon they thought it best, "not to prevent from this [knowledge] any Muslim."10 This tradition, which I will call henceforth "the coercion tradition," has attracted a good deal of scholarly attention during the last century and a half of oriental studies. ${ }^{11}$ Even though at variance about aspects of its interpretation, scholars who studied this tradition took it for gran-

10 'Abd al-Razzāq al-Ṣanānī, Muṣannaf, ed. Ḥabīb al-Raḥmān al-A'ẓamī, 12 vols. 2nd ed. (Beirut: al-Maktab al-islāmī, 1403/1983), 11:258, no. 20486. I read the clause akrah*-nā 'alay-

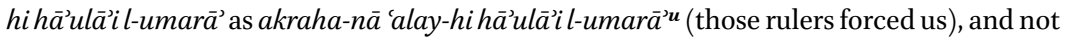
akrah-nā 'alay-hi hä ulā'i l-umarä'a (we forced it on those rulers), as suggested by Sprenger ("On the origin and progress of writing down historical facts among the Musalmans," Journal of the Asiatic Society of Bengal 25, no. 4 (1856): 322). Although grammatically possible, Sprenger's reading contradicts numerous other traditions that clearly assert that writing down Tradition was an Umayyad initiative in which they embroiled al-Zuhrī and other scholars.

11 Goldziher interpreted this remarkable report as a witness to al-Zuhrīs "willingness to lend his name [...] to the government's wishes" (Muhammedanische Studien, Zweiter Theil (Halle a. S.: Max Niemeyer, 189o), 38. I cite the translation according to Ignaz Goldziher, Muslim Studies, vol. 2, trans. C.R. Barber and S.M. Stern (London: George Allen \& Unwin Ltd, 1971), 47). Abbott identified the issue at stake in this and similar reports as the writing of Tradition. She asserted that, apart from royal pressure, al-Zuhrī agreed to record Tradition because he realized that written fixation of knowledge was an important means to check the influx of spurious traditions from the eastern provinces of the caliphate, to prevent orally transmitted lore from being forgotten, and to limit the influence of non-Arabs (mawālī) on nascent Islamic sciences (Studies in Arabic Literary Papyri, vol. 2: Qur'ānic Commentary and Tradition (Chicago: University of Chicago Press, 1967), 3334). Schoeler ("Oral Torah and Hadīt: Transmission, Prohibition of Writing, Redaction," in The Oral and Written in Early Islam, ed. James E. Montgomery, trans. Uwe Vagelpohl (London: Routledge, 2006), 122-123) and Michael Cook ("The Opponents of the Writing of Tradition in Early Islam," Arabica 44, no. 4 (1997): 46o-461, §42) used al-Zuhrîs statements to argue that an important transition from oral to written transmission of hadith was taking place at the turn of the first century AH/ca. $718 \mathrm{CE}$. Aspects of the same tradition were discussed by Fuat Sezgin (Geschichte des Arabischen Schrifttums, Band 1: Qur'ānwissenschaften, Hadiut, Geschichte, Fiqh, Dogmatik, Mystik, bis ca. 430 H (Leiden: Brill, 1967), 74-75), Gautier H.A. Juynboll (Muslim Tradition: Studies in Chronology, Provenance and Authorship of Early hadīth (Cambridge: Cambridge University Press, 1983), 169, note 32), Michael Lecker ("Biographical Notes on Ibn Shihāb al-Zuhrī," Journal of Semitic Studies 41, no. 1 (1996): 24ff.), and Meir J. Kister (“... Là taqra’ü l-quràna 'alā l-muṣhafiyyīna wa-lā 
ted that al-Zuhrī used the expression kitāb al-ilm to designate "writing down knowledge." Accordingly, his statement was generally assumed to imply that before the rulers' intervention traditions had been transmitted almost exclusively by way of oral instruction.

In what follows, I will argue, from a form-critical perspective, that the expression kunnā nakrahu l-kitāab ("we were loath of al-kitāb") reflects a stage in the development of the coercion tradition that is older than the matn of the bundle's CL, 'Abd al-Razzāq al-Șanānī (d. 211/827), which included the expression kunnā nakrahu kitāab al-ilm ("we were loath of writing down knowledge"). I will suggest that the unqualified use of the word kitäb, meaning "writ" or "scripture," was part of the matn's original formulation, perhaps going back to al-Zuhrī, and that only at a subsequent stage of development the word al-ilm was added to kitāb as a second part of an iḍāfa compound, thereby transforming the expression into "writing down knowledge." Al-Zuhrī would seem to have expressed a peculiar loathness of scripture that refers to a Sitz im Leben different from the hitherto assumed transition from oral to written transmission of knowledge.

\section{$2 \quad$ A Methodological Excursus}

In my study of the historical development and textual composition of the coercion tradition, I employ a method known as isnād-cum-matn analysis (hereinafter, ICMA). ICMA makes use of basic concepts and procedural rules that were formulated in the works of, inter alios, Joseph Schacht, ${ }^{12}$ Josef van Ess, ${ }^{13}$ Gautier H.A. Juynboll, ${ }^{14}$ Iftikhar Zaman, ${ }^{15}$ Gregor Schoeler, ${ }^{16}$ and Harald Motzki. ${ }^{17}$ The scholars who apply this method start with gathering from extant hadith collections the largest possible number of variant traditions dealing with a

tạ̣milü l-'ilma 'ani l-șahafiyyìn ... Some Notes on the Transmission of Hadīth," Jerusalem Studies in Arabic and Islam 22 (1998): 157-162).

12 Joseph Schacht, Origins of Muhammadan Jurisprudence (Oxford: Clarendon Press, 1950), 171-175.

13 Josef van Ess, Zwischen Hadịt und Theologie: Studien zum Entstehen prädestinatianischer Überlieferung (Berlin: Walter De Gruyter, 1975).

14 Juynboll, Encyclopedia, xvii-xxxiii, and his earlier works cited thereto.

15 Iftikhar Zaman, "The Evolution of a Hadith:Transmission, Growth and the Science of Rijal in a Hadith of Sa'd B. Abī Waqqas" (PhD diss., University of Chicago, 1989).

16 Schoeler, Charakter und Authentie.

17 Harald Motzki, "Dating Muslim Traditions: A Survey," Arabica 52, no. 2 (2005): esp. 250252 , and his earlier works cited thereto. 
single issue, the only condition being that these traditions be mentioned with their asānìd. Next, the names of all transmitters from the purported original speaker (say, the Prophet (d. 11/632)) to the respective hadith collector (say, 'Abd al-Razzāq al-Ṣan'ānī (d. 211/827)) are recorded in a graphical diagram in chronological succession. As it often happens, two or more asānīd converge on a single transmitter, who, therefore, is considered a key figure, that is, a possible historical transmitter of the tradition at issue. To determine the key figure's status, which is the most challenging part of ICMA, I combine isnād-analysis with meticulous analysis of the tradition's matn. ${ }^{18}$ The historical transmitters at the higher levels of the isnād bundle are partial common links (PCLs); if the PCL transmissions share a common historically verifiable source, this source is the bundle's common link (CL). Unless proven otherwise, the CL is the originator of the reconstructed tradition.

No collections by PCLS or CLS who flourished in the second/eighth century have been preserved, while later collectors convey their traditions with various degrees of structural and textual dissimilarity. It is, therefore, critically important to reconstruct the mutūn of the PCLs and the CL with the greatest possible degree of accuracy. Only in this case may we ascertain the historicity of transmission and recover the source tradition, either partly or in full, from the welter of later redactional changes. To reconstruct the wording of the coercion tradition, whenever possible I will deploy the following text-critical criteria:

- Priority of occurrence. This criterion accords priority to the formulations recorded by the compilers of surviving hadith collections who stand next to the PCL/CL.

- Frequency of use. This criterion gives prominence to the most widespread formulation within a group of cognate mutūn converging on a common transmitter.

- Conceptual transparency. According to this criterion, vaguely formulated mutūn predate their conceptually clearer and more elaborate counterparts.

- Semantic consistency. Contradictions or redundancies within an individual matn suggest editorial reworking. ${ }^{19}$

18 For details, see Pavel Pavlovitch, The Formation of the Islamic Understanding of Kalāla in the Second Century AH (718-816 CE): Between Scripture and Canon (Leiden: Brill, 2016), 2256 .

19 For a nuanced description of these criteria, see Pavlovitch, Formation, 37-40. 


\section{The Historical Development of al-Zuhrī's Tradition}

A list of onomastic abbreviations in Fig. 5.1.:

\begin{tabular}{|c|c|c|c|}
\hline A. & 'Alī & IABr. & Ibn 'Abd al-Barr \\
\hline AA. & Abū al-'Abbās & IAKh. & Ibn Abī Khaythama \\
\hline $\mathrm{AB}$. & Abū Bakr & IH. & Ibn Hanbal \\
\hline Ah. & Ahmmad & $\mathrm{IHj}$. & Ibn Hajar \\
\hline 'Al. & 'Abdallāh & Iḥ. & Ishāāq \\
\hline 'AR. & 'Abd al-Raḥmān & IJ. & Ibn Jabala \\
\hline 'AMk. & 'Abd al-Malik & IKth. & Ibn Kathīr \\
\hline AN. & Abū Nu'aym & IS. & Ibn Sa'd \\
\hline 'AWrth. & 'Abd al-Wārith & Ism. & Ismāīll \\
\hline BH. & Bishr b. al-Hakam & Isr. & Isrāīl \\
\hline Bhq. & al-Bayhaqī & Khld. & Khālid \\
\hline Bk. & Bakr & Khțb. & al-Khațīb al-Baghdādī \\
\hline Bldh. & al-Balādhurī & Manș. & Manșūr \\
\hline Dbr. & al-Dabarī & Mslm. & Muslim \\
\hline Dhhb. & al-Dhahabī & M. & Muhammad \\
\hline Drm. & al-Dārimī & Qsm. & Qāsim \\
\hline Fsw. & al-Fasawī & Ys. & Yūnus \\
\hline Hmd. & Hammād & Bgh. & Baghdad \\
\hline Hus. & Husayn & Md. & Medina \\
\hline IA. & Ibn 'Asākir & Ym. & Yemen \\
\hline
\end{tabular}

The coercion traditions center around two main key figures: 'Abd al-Razzāq alȘan'ānī and Sufyān b. 'Uyayna (see Fig. 5.1). In addition, an isolated transmission passes through Ibrāhīm b. al-Mundhir to al-Zuhrī. Let us check if any of these traditionists is a historical transmitter.

\subsection{The isnād Evidence}

The asānìd in Fig. 5.1 have al-Zuhrī as their lowest point of convergence. This evidence is, nevertheless, uncertain, owing to the single-strands of transmission that always separate al-Zuhri from the earliest collector/key-figure in the respective isnād bundle. While keeping in mind this limitation, let us try to establish if 'Abd al-Razzāq, Sufyān b. 'Uyayna, or Ibrāhīm b. al-Mundhir may have transmitted a tradition that goes back to al-Zuhrī.

'Abd al-Razzāq's transmission passes through his teacher, the renowned Yemeni traditionist Ma'mar b. Rāshid (d. 153-154/770-771). Indisputable though it may seem in its general outlines, 'Abd al-Razzāq's massive corpus 


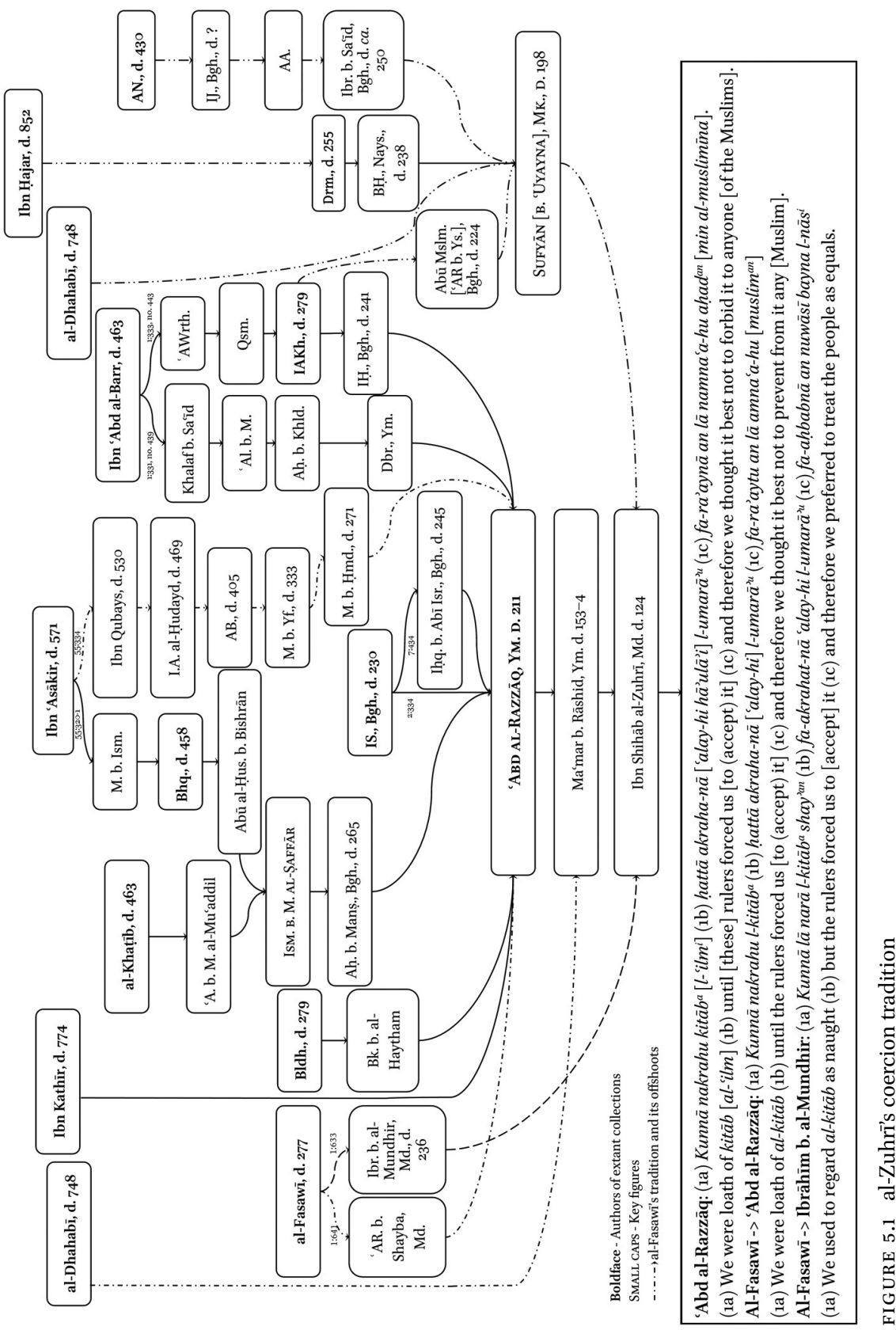


on the authority of Ma'mar is open to questions and doubt when it comes to its specific aspects. Harald Motzki was the most eloquent advocate of the authenticity of the transmission 'Abd al-Razzāq $\rightarrow$ Ma'mar. In a study of 3,810 asānìd from 'Abd al-Razzāq's Mușannaf, Motzki observed that at the level immediately below 'Abd al-Razzāq these asānìd divide unevenly between four major transmitters-Ma'mar b. Rāshid (32\%), Ibn Jurayj (29\%), Sufyān alThawrī (22\%), and Sufyān b. 'Uyayna (4\%)—and go less important transmitters. Significantly, a similar heterogeneous distribution obtains at the next lower level of transmission. This diversity of transmission led Motzki to conclude that 'Abd al-Razzāq's transmission of the above four hadith corpora is generally authentic. ${ }^{20}$ The authenticity of 'Abd al-Razzāq's corpus on the authority of Ma'mar in general, however, does not guarantee the genuineness of its every single constituent tradition. In his critique of Motzki's method, Juynboll pointed out that a blanket statistical approach to hadith corpora lacks the precision to discriminate between authentic and potentially inauthentic traditions. Thus, for instance, collections composed in the third/ninth century, such as Ibn Hanbal's Musnad, contain numerous traditions on the authority of 'Abd al-Razzāq that are not part of his Mușannaf. If Ibn Hanbal could invent scores of traditions, as Juynboll assumes, 'Abd al-Razzāq might have equally indulged in inventing and falsely ascribing hadith to his alleged sources. ${ }^{21}$

Another wave of criticism was directed against Motzki's methodological assumption that the heterogeneity of transmission of one collector from multiple sources indicates the authenticity of that collector's corpus. Thus, Gledhill ${ }^{22}$ took Motzki to task for not studying the formal characteristics of transmission from one source to a plurality of recipients - an inverse procedure that Gledhill designated as "homogeneity principle." Against Motzki's heterogeneity principle, which equates diversity with authenticity, Gledhill posited that whenever several collectors transmit from a shared source, their asānìd ought to have similar formal characteristics. To test the homogeneity criterion, Gledhill examined the transmissions of 'Abd al-Razzāq and Ibn Abī Shayba through 'Ațā' b. Abī Rabāh, and he demonstrated that these two strands differ considerably in their formal characteristics. Thus, diversity of transmissions reach-

$20 \quad$ Harald Motzki, The Origins of Islamic Jurisprudence: Meccan Figh before the Classical Schools, trans. Marion H. Katz (Leiden: Brill, 2002), $58 \mathrm{ff}$.

21 Gautier H.A. Juynboll, "New Perspectives in the Study of Early Islamic Jurisprudence," Bibliotheca Orientalis 49, no. 3-4 (1992): 359-36o.

22 Paul Gledhill, "Motzki's Forger: The Corpus of the Follower 'Ațā' in Two Early 3rd/9thCentury Hadìth Compendia," Islamic Law and Society 19, no. 1-2 (2012): 171-189. 
ing one collector from several earlier sources goes in tandem with diversity of transmissions issuing from each of these sources to several later collectors, which, according to Gledhill's criteria, undermines Motzki's heterogeneity principle.

To wrap up our review of Motzki's corpus analysis, it is necessary to note that, to date, it does not seem to have passed the test of falsifiability. To my knowledge and experience with hadith analysis, any notable body of traditions clustering around a single transmitter exhibits the diverse distribution among several principal informants that Motzki observed in the case of 'Abd al-Razzāq (see, for instance, my limited survey of Ibrāhīm b. al-Mundhir's corpus at the end of the present sub-section). Unless we are able to falsify Motzki's method on its own terms, that is, discover a corpus wherein traditions are uniformly distributed among a group of alleged informants of a single collector, this method will remain an important yet epistemologically questionable tool of studying the provenance and authenticity of Muslim traditions.

Be that as it may, the clash of opinions about the authenticity of 'Abd alRazzāq's asānìd prevents us from reaching a definite conclusion about the reliability of his single-strand transmission on the authority of Ma'mar b. Rāshid $\rightarrow$ al-Zuhrī in the present case. The asānīd through Sufyān b. 'Uyayna may provide significant hints about 'Abd al-Razzāq's source, but they are problematic, for several reasons.

First, 'Abd al-Razzāq's version of the coercion tradition is preserved in his Mușannaf, and it is cited on his authority by nine later collectors, which leaves no doubt as to 'Abd al-Razzāq's CL status. By contrast, there is no extant collection with Sufyān b. 'Uyayna's traditions, while he is cited by only two early collectors (al-Dārimī and Ibn Abī Khaythama), based on single-strand asānìd. These two transmissions served as the source-either stated or concealedof the other transmissions in the Ibn 'Uyayna cluster. According to Juynboll's criteria, the absence of PCLs and direct collectors above the level of Sufyān makes the association of the coercion tradition with him a suspect of forgery.

Second, as shown in Fig. 5.1 two Baghdadis and one Naysābūri transmitter from the following generation purportedly transmitted on the authority of the Meccan Sufyān b. 'Uyayna. But why do Meccans appear to have neglected a tradition of their famous fellow countryman? One may argue that all Meccan asānīd above Ibn 'Uyayna had been lost, but such an inference from silence can hardly substantiate Sufyān's CL status.

Third, biographical reports make much of Sufyān's excellent memory. He did not possess any books, and if he recorded traditions at all, this never happened 
before he had memorized them first. ${ }^{23}$ Given Sufyān's expertise in exegesis and hadith interpretation (tafsir al-hadith), ${ }^{24}$ he must have paid considerable attention to the legal and exegetical content of his traditions. It is striking that being an incisive exegete and jurisprudent who always learned traditions by heart, Sufyān nevertheless transmitted a hadith that goes against his opinion that hadith should be communicated orally.

Fourth, Sufyān b. 'Uyayna cites al-Zuhrī, who died seventy-four lunar years earlier. Given that in biographical lexica and hadith-critical works Sufyān is an exemplary mudallis (obfuscator of transmission), this extensive temporal gap raises serious doubts on the authenticity of his present isnād through al-Zuhri. ${ }^{25}$ Our suspicion increases as we consider the formal expressions in which Sufyān describes his communication with al-Zuhrī. According to Ibn Abī Khaythama, Sufyān stated, tahaddathū-nā 'an al-Zuhrī (they told us from alZuhrī), by which he likely refers to several intermediate transmitters without specifying if he heard directly from any of them. ${ }^{26}$ Ibn Abī Khaythama's contemporary, al-Dārimī, makes use of the generic preposition 'an (from) to describe the way of communication between Sufyān and al-Zuhrī, which, in this case, most likely conceals a major flaw in transmission. ${ }^{27}$

To sum up, the transmission both above and below Ibn 'Uyayna is beset by serious isnād problems. Given the degree of textual agreement between subclauses 1a and $1 \mathrm{~b}$ in the transmissions of al-Dārimī and Ibn Abī Khaythama through Ibn 'Uyayna, on the one hand, and al-Fasawi's tradition through 'Abd al-Razzāq al-Ṣan'ānī, on the other, one may think that the former two traditions were modeled on al-Fasawi's variant. Those who ascribed to Ibn 'Uyayna statements that apparently lend support to writing down hadith may have attempted to undermine his oralist attitude towards transmission of knowledge. ${ }^{28}$

23 al-Mizzī, Tahdhīb al-Kamāl fì asmā̄ al-rijāl, ed. Bashshār Ma'́rūf, 35 vols., 2nd ed. (Beirut: Mu’assasat al-Risāla, 1983/1403), 11:189.

24 al-Rāmahurmuzī, al-Muhaddith al-fāṣil bayna l-rāwī wa-l-wā̄ī, ed. Muhammad al-Khațīb, 1st ed. (Beirut: Dār al-Fikr, 1391/1971), 241, no. 146.

25 For a discussion of Sufyān's asānīd, see Tilman Nagel, "Ḥadīt-oder: Die Vernichtung der Geschichte," in XXV. Deutscher Orientalistentag, Vorträge, München 8.-13.4.1991, ed. Cornelia Wunsch, zDM Supplement 10 (Stuttgart, Franz Steiner, 1994), 120-124; Pavlovitch, Formation, 81 , note 38 and the sources cited thereto.

26 Ibn 'Abd al-Barr, who transmits through Ibn Abī Khaythama, has tukhbarūna 'an al-Zuhrī (you [pl.] are informed about al-Zuhri).

27 According to al-Ḥākim al-Naysābūrī, each isnād in which Sufyān reports on the authority of al-Zuhrī without explicitly mentioning direct audition $\left(\operatorname{sam} \bar{a}^{c}\right)$ represents a case of tadlīs (al-Madkhal ilā márifat Kitāab al-Iklül, ed. Aḥmad al-Sallūm (Beirut: Dār Ibn Ḥazm, 1423/2003), 112-114).

28 That Sufyān was involved in a dispute about permissibility of oral transmission, either 
The third isnād through al-Zuhrī is recorded in al-Fasawì's al-Ma'rifa wal-tārīkh (Knowledge and history) on the authority of Ibrāhīm b. al-Mundhir (d. 236/850). The gap of 112 lunar years between the death dates of Ibrāhim and al-Zuhrī suggests that the former used either an intermediate transmitter or a written source. With regard to the first possibility, it will be remembered, biographical lexica regularly mention Sufyān b. 'Uyayna as one of Ibrāhīm b. alMundhir's main informants. ${ }^{29}$ These assertions do not seem to find support (at least in quantitative terms) in the frequency of occurrence of the isnād Ibrāhìm b. al-Mundhir $\rightarrow$ Ibn 'Uyayna in al-Fasawi's above collection, which is one of the earliest works to include Ibrāhīm's asānìd. Al-Fasawī's corpus through Ibrāhīm comprises eighty-two asānìd of which only four include Ibn 'Uyayna as Ibrāhīm's informant. Nineteen of the above eighty-two asānìd pass through al-Zuhrī. By far the most widespread among them is the isnād Muhammad b. Fulayḥ $\rightarrow$ Mūsā b. 'Uqba $\rightarrow$ al-Zuhrī (twelve occurrences, mainly in the field of maghāzī), distantly trailed by Ibn Wahb $\rightarrow$ Yūnus b. Yazīd $\rightarrow$ al-Zuhrī (three occurrences). The isnād Ibrāhīm b. al-Mundhir $\rightarrow$ Sufyān $\rightarrow$ al-Zuhrī occurs only twice. A similar tendency marks Ibn Shabba's (d. 264/877) Tärīkh al-Madina (Chronicle of Medina), which includes Ibn 'Uyayna in none of the fifty-eight transmissions through Ibrāhīm b. al-Mundhir. The negligible rate of occurrence of the isnād Ibn al-Mundhir $\rightarrow$ Ibn 'Uyayna $\rightarrow$ al-Zuhri in the above two works may be explained by their authors' preference for historical (maghāzi $)$ reports about the Prophet, ${ }^{30}$ which were hardly the pursuit of the jurist Ibn 'Uyayna. Even so, this does not prove that Ibn 'Uyayna is the suppressed link in the isnād al-Fasawī $\rightarrow$ Ibn al-Mundhir $\rightarrow$ ? $\rightarrow$ al-Zuhrī. On the other hand, we do not have isnād or matn indications to the effect that al-Fasawi forged his tradition on the authority of Ibrāhīm b. al-Mundhir, who may therefore be regarded a historical transmitter of that tradition. Various factors may have contributed to the peculiarities of his version, as, for instance, poor memory or transmission from a little-known source. Either flaw could have nurtured the biographical reports according to which Ibrāhīm related unrecognized, hence, questionable

personally or by way of later ascription, is suggested by his association with traditions that argue both against and for writing (Cook, "Opponents," 465-467, §§ 49-52; 477, § 75). Ibn Abī Ḥātim al-Rāzī, al-Jarh wa-l-ta'dūl, 9 vols. (Beirut: Dār Iḥyā’ al-turāth al-ārabī, n.d.), 2:139, no. 450; Ibn Hibbān, Kitāb al-Thiqāt, ed. Muhammad 'Abd al-Mu'īd Khān, 10 vols. (Mu’assasat al-Kutub al-thaqafiyya, 1973/1393), 8:72; al-Khațīb al-Baghdādī, Tārīkh Baghdād, ed. Bashshār Ma'rūf, 17 vols. (Beirut: Dār al-Gharb al-islāmī, 1422/2001), 7:122; al-Mizzī, Tahdhīb, 1:207; Ibn Ḥajar, Tahdhīb al-Tahdhīb, 12 vols. (Hyderabad, 1325), 1:166.

30 Muhammad b. Fulayḥ was a transmitter of Mūsā b. 'Uqba's Kitāb al-Maghāzī (Book of raids) (GAS, 287). 
or even repudiated, traditions (manākir). ${ }^{31}$ Be that as it may, in the present case it is important to note that Ibrāhīm transmitted the word kitāb without any additions, which aligns with a similar use in al-Fasawīs transmission through 'Abd al-Razzāq. Apart from a deliberate adjustment of one of the two mutūn, which would be inexplicable given the exegetical oddity of the unqualified use of kitāb, this correspondence raises the possibility that in both cases al-Fasawi has recorded an old narrative that pre-dates both Ibrāhīm b. al-Mundhir and the CL, 'Abd al-Razzāq al-Ṣan'ānī.

\subsection{The matn Evidence}

Our isnād analysis points to 'Abd al-Razzāq al-Ṣan'ānī as the most certain CL of the coercion tradition. There are indications, nevertheless, that this tradition, or parts thereof, may have been put into circulation earlier than 'Abd al-Razzāq. To examine this possibility, I turn now to the mutūn associated with the three key figures citing al-Zuhrī, to wit, 'Abd al-Razzāq, Ibn 'Uyayna, and Ibrāhīm b. al-Mundhir.

To facilitate our analysis and to save space, I combine the mutūn into a single matn-composite (MC), divided into three sub-clauses. Boldface indicates the similar parts of the mutūn. Dissimilar parts of the same mutün appear in square brackets, if they consist of a few words, or in curly brackets, if they are longer. After each point of difference, an uppercase number indicates its carrier isna $\bar{d}$ as listed before the matn-composite.

\subsection{1 'Abd al-Razzāq al-Ṣanān̄̄}

Matn-composite MC-1

1. 'Abd al-Razzāq $\rightarrow$ Ma'mar $\rightarrow$ al-Zuhrī:32

2. Ibn Sa'd $\rightarrow$ 'Abd al-Razzāq $\rightarrow$ Ma'mar $\rightarrow$ al-Zuhrīi:33

3. Ibn Sa'd $\rightarrow$ Isḥāq b. Abī Isrāīl $\rightarrow$ 'Abd al-Razzāq $\rightarrow$ Ma'mar $\rightarrow$ al-Zuhrī:34

4. Al-Fasawī $\rightarrow$ Abū Bakr b. 'Abd al-Malik $\rightarrow$ 'Abd al-Razzāq $\rightarrow$ Ma'mar $\rightarrow$ alZuhrī: 35

5. Al-Balādhurī $\rightarrow$ Bakr b. Haytham $\rightarrow$ 'Abd al-Razzāq $\rightarrow$ Ma'mar $\rightarrow$ al-Zuhrīi: ${ }^{36}$

31 Khațīb, Tārīkh, 7:124.

32 'Abd al-Razzāq, Mușannaf, 11:258, no. 20486.

33 Ibn Sa'd, al-Ṭabaqāt al-kubrā, ed. 'Alī 'Umayr, 11 vols., 1st ed. (Cairo: Maktabat al-Khanjī, 1421/2001), 2:334.

34 Ibn Sacd, 7:434.

35 al-Fasawī, al-Márifa wa-l-tārīkh, ed. Akram al-'Umarī, 4 vols., 1st ed. (Medina: Maktabat al-Dār, 1410), 1:641.

36 al-Balādhurī, Ansāb al-ashrāf, eds. Suhayl Zakkār and Riyāạ Zarkalī, 13 vols., 1st ed. (Beirut: Dār al-Fikr, 1417/1996), 10:48. 
6. Ibn Abī Khaythama $\rightarrow$ Aḥmad b. Ḥanbal $\rightarrow$ 'Abd al-Razzāq $\rightarrow$ Ma'mar $\rightarrow$ al-Zuhrī, qāla [Ma'mar?]: Sami'tu-huyaqūlu: ${ }^{37}$

7. Al-Bayhaqī $\rightarrow$ Abū l-Ḥusayn b. Bishrān $\rightarrow$ Ismā̄īl al-Ṣaffār $\rightarrow$ Ahmad b. Manșūr $\rightarrow$ 'Abd al-Razzāq $\rightarrow$ Ma'mar $\rightarrow$ al-Zuhrī:38

8. Al-Khațīb al-Baghdādī $\rightarrow$ 'Alī b. Muhammad b. 'Abdallāh al-Mu'addil $\rightarrow$ Ismāēil b. Muhammad al-Ṣaffār $\rightarrow$ Ahmad b. Manșūr $\rightarrow$ 'Abd al-Razzāq $\rightarrow$ Macmar $\rightarrow$ al-Zuhrī:39

9. Ibn 'Abd al-Barr $\rightarrow$ Khalaf b. Saīd $\rightarrow$ 'Abdallāh b. Muḥammad $\rightarrow$ Aḥmad b. Khālid $\rightarrow$ Isḥ̄a b. Ibrāhīm $\rightarrow$ 'Abd al-Razzāq $\rightarrow$ Ma'mar $\rightarrow$ al-Zuhrī:40

10. Ibn 'Asākir $\rightarrow$ Abū al-Ḥasan b. Qubays $\rightarrow$ Abū al-Ḥasan b. Abī al-Ḥudayd $\rightarrow$ jadd ${ }^{u}-h u$ Abū Bakr $\rightarrow$ Muḥammad b. Yūsuf $\rightarrow$ Muḥammad b. Ḥammād $\rightarrow$ 'Abd al-Razzāq $\rightarrow$ Ma'mar $\rightarrow$ al-Zuhrī: ${ }^{41}$

11. Al-Dhahabī $\rightarrow[\ldots] \rightarrow$ Mámar $\rightarrow$ al-Zuhrīi:42

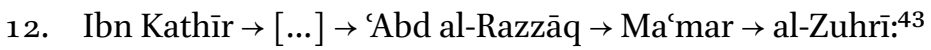

\section{1a Kunnā nakrahu}

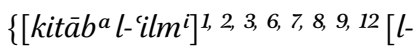
kitāa $\left.\left.b^{a}\right]^{4,10,11}\right\} 1,2,3,4,6,7,8,9,10,11,12$ $\{\text { an yuktaba'an-nā } l \text {-'ilm }\}^{5}$

lb hattā akraha-nā ['alay-hi] 2, 3, 4, 5, 6, 7, 8, 9, 10, 11, $12[$ hä'ulä'i $]$ 1, 2, 3, 5, 6, 7, 8, 9, 12 $\left[\right.$ l-umarä̀u $\left.^{\jmath}\right] 1,2,3,4,5,7,8,9,10,11,12$

\section{We were loath of}

$\left\{[\text { writing down knowledge }]^{1,2,3,6,7,8,9,12}\right.$ $[$ al-kitāb] $4,10,11\} 1,2,3,4,6,7,8,9,10,11,12$ \{to have knowledge written down from us $\}^{5}$

until [these $]^{1,2,3,5,6,7,8,9,12}[\text { rulers }]^{1,2,3,4}$, $5,7,8,9,10,11,12$ forced us [to (accept) it] $]^{2,3,4}$, $5,6,7,8,9,10,11,12$

37 Ibn Abī Khaythama, al-Tārīkh al-kabīr, ed. Șalāḥ Halal, 4 vols., ıst ed. (Cairo: al-Farūq alhadītha, 1424/2004), 2:248, no. 2714. Ibn 'Abd al-Barr (Jāmi' bayān al-ilm wa-faḍli-hi, ed. Abū al-Ashbāl al-Zuhayrī, 2 vols., 1st ed. [Dammam: Dār Ibn al-Jawzī, 1994], 1:333, no. 443) cites the same matn through Ibn Abī Khaythama. On this account, I do not cite Ibn 'Abd al-Barr no. 443 as a separate matn variant.

38 al-Bayhaqī, al-Madkhal ilā al-Sunan al-kubrā, ed. Muhammad al-A'ẓamī, 2 vols., 2nd ed. (Riyadh: Aḍwā' al-salaf, 1420), 2:222, no. 739. Ibn 'Asākir (Tärīkh madinat Dimashq, ed. 'Umar al-'Amrawī, 8o vols. [Beirut: Dār al-Fikr, 1415-1421/1995-200o), 55:320-321] cites alBayhaqi's tradition with no differences of note; hence, I do not include the latter among the matn variants in MC-1.

39 Khațîb, Taqyīd al-'ilm, ed. Yūsuf al-'Ishsh (Damascus: al-Ma'had al-faransī bi-Dimashq, 1949), 107.

$40 \quad$ Ibn 'Abd al-Barr, Jāmi', 1:331-332, no. 439.

41 Ibn 'Asākir, Tārīkh, 55:334.

42 al-Dhahabī, Siyar a' lām al-nubalā', ed. Shu'ayb al-Arna'ūț, 39 vols. (Beirut: Mu’assasat alRisāla, 1401-1417/1981-96), 5:334.

43 Ibn Kathīr, al-Bidāya wa-l-nihāya, ed. 'Abdallāh al-Turkī, 21 vols., ıst ed. (Cairo: Dār Hajar, 1417-1420/1997-1999), 13:134. 
$1 \mathrm{c}$

$\{\text { fa-ra'aynā an lā [namna'a-hu }]^{1,3,5,}$ 6, 7, 8, 9, 12 [yumna'a-hu $]^{2}$ ahad an/un min al-muslimina $\}^{1,2,3,5,6, ~ 7, ~ 8, ~ 9, ~} 12$ $\{$ fa-ra'aytu an lā amna'a-hu muslim $\left.^{\text {an }}\right\}^{4,10,11}$ \{and, therefore, we thought it best [not to forbid it to] $]^{1,3, ~ 5, ~ 6, ~ 7, ~ 8, ~ 9, ~} 12$ any Muslim [should not be prevented from it] $\left.{ }^{2}\right\}^{1,2,3,5,6 \text {, }}$ $7,8,9,12$

And, therefore, I thought it best not to forbid it to any Muslim $\}^{4,10,11}$

Since 'Abd al-Razzāq is the point of convergence of eleven asānīd, while the printed edition of his Musannaf includes the coercion tradition, we are safe to conclude that he is the $\mathrm{CL}$ of the version summarized in $\mathrm{MC}-\mathbf{1}$. To reconstruct 'Abd al-Razzāq's original formulation, which may have differed from what is preserved in the extant version of the Mușannaf, let us analyse each clause as mentioned in the variant mutūn.

Before all, we note that the matn evidence falls into two clearly distinguishable groups. First, 'Abd al-Razzāq's formulation as found in the Mușannaf and most later collections citing 'Abd al-Razzāq; second, al-Fasawī's transmission on the authority of 'Abd al-Razzāq. Although based on an isnād that does not include al-Fasawī, Ibn 'Asākir 55:334 cites a matn that is well-nigh identical to al-Fasawī's matn, which suggests that one of Ibn 'Asākir's informants copied al-Fasawī's formulation. ${ }^{44}$ So too for al-Dhahabì's tradition on the authority of Ma'mar b. Rāshid. Its isnād does not include intermediate transmitters, and is

44 Ibn 'Asākir's isnād bears all signs of elevation ('uluwww). By such asānīd, featuring large temporal gaps between the death dates of several successive transmitters, Muslim traditionists mapped the shortest way to a key transmitter of a given tradition-in the present case 'Abd al-Razzāq (see the dashed-and-dotted line in Fig. 5.1). Ibn 'Asākir's informant, Abū al-Ḥasan 'Alī b. Ahmmad b. Manșūr b. Qubays died in 530/1136, sixty-one lunar years after his informant, Abū al-Ḥasan Aḥmad b. 'Abd al-Wāḥid b. Muhammad b. 'Uthmān b. Abī al-Ḥudayd (d. 469/1076-1077). Aḥmad b. 'Abd al-Wāhiid died sixty-four lunar years after his grandfather, Abū Bakr Muḥammad b. Aḥmad b. 'Uthmān (d. 405/1015), on whose authority he transmits the present hadith. Abū Bakr died seventy-two lunar years after his informant Muhammad b. Yūsuf b. Bishr al-Harawī who reportedly died at a centenarian age in 333/945 (al-Dhahabī, Ṭabaqāt al-huffāz, sst ed. [Beirut: Dār al-Kutub al-'ilmiyya, 1403/1983], 349). Given al-Harawì's prodigious longevity, it is not surprising that he died sixty-two lunar years after his informant Muhammad b. Ḥammād al-Ṭihrānī (d. 271/884-885). Al-Ṭihrānī, in turn, died seventy lunar years after 'Abd al-Razzāq. Ibn 'Asākir's isnād certainly involved written transmission at its later stages, but the long temporal gaps between the death dates of the transmitters immediately above 'Abd al-Razzāq, and al-Harawī's alleged longevity, evoke suspicion. Since al-Harawī and al-Ṭihrānī were both active in the eastern part of the caliphate, as was al-Fasawī, each of them may have unavowedly copied al-Fasawī's tradition. The older, al-Tihrānī, would have ascribed the borrowed tradition directly to 'Abd al-Razzāq, whereas the younger, al-Harawī, would have used al-Ṭihrānī as an intermediate transmitter in his ascription to 'Abd al-Razzāq. 
thereby suspended (mu'allaq) in the parlance of Muslim hadith critics, whereas its matn is identical to that of al-Fasawī. At the end of the present section, I will discuss al-Dhahabī's reason to resort to a mu'allaq isnād excluding al-Fasawī's name. In the following analysis, I treat Ibn 'Asākir 55:334 and al-Dhahabī's tradition as offshoots of al-Fasawi's version (see the dash-and-dotted lines in Fig. 5.1) rather than independent evidence for the reconstruction of 'Abd al-Razzāq's CL version.

Sub-clause 1a. All transmissions on the authority of 'Abd al-Razzāq include the expression kunna nakrahu (we were loath of), which, therefore, must have been his original formulation. The next part of this sub-clause is, however, textually fluid. The idâfa compound kitāb al-ilm (writing of knowledge) is most widely attested, but al-Fasawī transmits only the word kitāb, and al-Balādhurī has an yuktaba 'an-nā l-ilm ${ }^{u}$ (to have knowledge written down from us). Priority of occurrence and frequency of use suggest that kitäb al-ilm was 'Abd al-Razzāq's original formulation, but the important criterion of conceptual transparency calls for qualifying this conclusion in a significant way. It is hard to imagine that al-Fasawī truncated kitāb al-ilm to its first component, which in this context may denote "writing," "document," or "holy writ." Rather than a later abridgement, this ambiguous use represents the lectio difficilior, that is, the earliest form of the coercion tradition. Disturbed by the insinuation that al-Zuhrī may have been loath of scripture, later transmitters, who were oblivious of the hadith's original Sitz im Leben, transformed the dogmatically perilous kitāb into the innocuous kitāb al-iilm. Al-Balādhurì's variant, an yuktaba 'an-nā l-ilmu, marks the most mature stage of these reformulations; here, any ambiguity as to the object of al-Zuhrî's aversion is removed by discarding the word kitāb altogether. Thus, our text-critical criteria suggest two stages in the development of sub-clause 1a. Priority of occurrence and frequency of use point to kitāb al-ilm as being the expression in 'Abd al-Razzāq's transmission. The criterion of conceptual transparency, however, suggests that this expression was but a clarifying reformulation of an earlier tradition in which al-Zuhrī expressed loathness of al-kitāb in general. Most likely, he was referring to events and concepts that had no bearing on the transmission of knowledge in early Islam, as, for instance, the redaction of the Qurān during the reign of the Umayyad caliph 'Abd al-Malik b. Marwān (r. 65-86/685705).

Sub-clause 1 b. Hattā akraha-nā (until [they] forced us) is present in all transmissions through 'Abd al-Razzāq; consequently, this expression must have been his original formulation. All but 'Abd al-Razzāq's tradition include the prepositional compound 'alay-hi (to it). Frequency of use tips the scales in favor of the numerically preponderant expression. If 'alay-hi was transmitted 
by 'Abd al-Razzāq as well, it should have been omitted by a later transmitter of the Musannaf. On the other hand, 'alay-hi is grammatically dispensable, and, therefore, it may have been inserted in the clause to emend an original lectio difficilior. The demonstrative pronoun $h \bar{a} u l a \bar{a} i$ does not occur in the transmission al-Fasawī $\rightarrow$ 'Abd al-Razzāq but is present in the other matn variants, including that in 'Abd al-Razzāq's Mușannaf. Once again, frequency of use strongly suggests that $h \bar{a} u l a \bar{a} i$ was part of 'Abd al-Razzāq's original transmission. Alternatively, the pronoun may be a supplementary element of fictionalization that aimed to highlight the word "rulers." Insofar as its absence does not affect the semantic structure of sub-clause $1 \mathrm{~b}$, al-Fasawi may have been aware of an old formulation pre-dating 'Abd al-Razzāq. The word umară’u (rulers) is not present in Ibn Abī Khaythama's tradition. Both priority of occurrence and frequency of use suggest that Ibn Abī Khaythama inadvertently omitted this part of 'Abd al-Razzāq's matn.

Sub-clause $1 c$. In this sub-clause, the narrations vary considerably. Ibn Sad transmits, fa-ra'aynā an lā yumna'a-hu ahad ${ }^{u n}$ min al-muslimina (and, therefore, we thought it best that no Muslim should be prevented from it); al-Fasawi has, fa-ra'aytu an lā amna'a-hu muslim ${ }^{a n}$ (and, therefore, I thought it best not to forbid it to any Muslim); the other collectors agree on fa-ra'aynā an lā namna'ahu ahad ${ }^{a n}$ min al-muslimina (and, therefore, we thought it best not to forbid it to any Muslim). Ibn Sad's passive voice is a likely scribal error: the consonantal skeletons of namna'u-hu (نمنعه) and yumna'u-hu (يمنعة) overlap with the exception of the initial consonant's diacritics. By contrast, the first-person singular form of the verb ra'aytu in al-Fasawi's tradition ought not to be dismissed as such an error. In all likelihood, it reflects al-Zuhrī's originally expressed personal opinion, which later transmitters recast in the first-person plural form, so as to extend its implicit viewpoint to a wider group of scholars. The grammatical disjuncture between the plural verbal and pronominal forms in sub-clauses $1 \mathrm{a}$ and $\mathrm{lb}$ and the singular verbal form in sub-clause $1 \mathrm{c}$ of al-Fasawi's tradition raises the possibility that the latter sub-clause was a secondary supplement to the former two. With regard to the concluding expression in sub-clause 1c, the single word muslim ${ }^{a n}$ (a Muslim) in al-Fasawi's transmission seems to represent an older form that preceded the longer expression ahad ${ }^{a n}$ min al-muslimina (any Muslim), found in the other transmissions through 'Abd al-Razzāq. The semantic structure of this expression suggests that it may have come into being when an original generic $a$ had $^{a n}$ was supplemented with the specifying min almuslimina. In the next sub-section, I will adduce specific evidence in support of this hypothesis.

To sum up, our form-critical analysis allows us to reconstruct two variant traditions. First, 'Abd al-Razzāq al-Ṣan'ānī transmitted the following matn: 


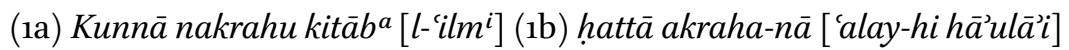
l-umarā’u (1c) fa-rảaynā an lā namna'a-hu ahad ${ }^{a n}$ [min al-muslimina].

(1a) We were loath of writing [down knowledge] (1b) until [these] rulers forced us [to (accept) it] (1c) and, therefore, we thought it best not to forbid it to anyone [of the Muslims].

'Abd al-Razzāq's version was likely based on an earlier matn that excluded the parts enclosed in square brackets. The second variant tradition, transmitted by al-Fasawi, stands closer to that hypothetical matn:

(1a) Kunnā nakrahu l-kitāo $b^{a}$ (1b) ḩattā akraha-nā ['alay-hi] l-umarāa ${ }^{\jmath}$ (1c) fa-ra’aytu an lā amna'a-hu muslim ${ }^{a n}$.

(1a) We were loath of al-kitāb (1b) until the rulers forced us [to (accept) it] (1c) and, therefore, I thought it best not to forbid it to any Muslim.

Al-Dhahabì's tradition that we discussed at the beginning of the present subsection may hold some clues about the composition and content of the matn prior to its collection and edition by the CL, 'Abd al-Razzāq al-Ṣan'ānī. As noted, al-Dhahabī's matn agrees verbatim with that of al-Fasawī, while his isnäd connects directly with 'Abd al-Razzāq's informant, Ma'mar b. Rāshid. Al-Dhahabī may have resorted to a suspended isnād because he viewed Ma'mar as the single most important transmitter of the hadith. Al-Dhahabì's reason to think so may only be guessed at, but we must take into account the possibility that, from his synoptic vantage point, he was likely alert to the substantial differences between the formulations of al-Fasawī and 'Abd al-Razzāq. If al-Dhahabī assumed that at the earlier level of transmission, represented by Ma'mar, the matn was uniform, by citing al-Fasawī's variant while excluding 'Abd al-Razzāq from the isnād, he would imply that al-Fasawī preserved al-Zuhrīs formulation better than 'Abd al-Razzāq did.

\subsubsection{Sufyān b. 'Uyayna}

Matn-composite MC-2

1. Al-Dārimī $\rightarrow$ Bishr b. al-Hakakam $\rightarrow$ Sufyān $\rightarrow$ al-Zuhrīi:45

2. Ibn Abī Khaythama $\rightarrow$ Abū Muslim $\rightarrow$ Sufyān $\rightarrow$ al-Zuhrīi:46

45 al-Dārimī, Sunan, ed. Ḥusayn al-Dārānī, 4 vols., 1st ed. (Riyadh: Dār al-Mughnī, 1421/20oo), 1:392, no. 418.

46 Ibn Abī Khaythama, Tärīkh, 2:251, no. 2728. 
3. Abū Nu'aym $\rightarrow$ Abū Hâamid b. Jabala $\rightarrow$ Abū al-'Abbās $\rightarrow$ Ibrāhīm b. Saīd $\rightarrow$ Sufyān $\rightarrow$ al-Zuhrī: ${ }^{47}$

4. Ibn 'Abd al-Barr $\rightarrow$ 'Abd al-Wārith $\rightarrow$ Qāsim $\rightarrow$ Ibn Abī Khaythama $\rightarrow$ Abū Muslim $\rightarrow$ Sufyān $\rightarrow$ al-Zuhrī: ${ }^{48}$

5. Al-Dhahabī $\rightarrow[\ldots] \rightarrow$ Ibn 'Uyayna $\rightarrow$ al-Zuhrī: ${ }^{49}$

6. Ibn Ḥajar $\rightarrow[\ldots] \rightarrow$ al-Dārimī $\rightarrow$ Bishr b. al-Ḥakam $\rightarrow$ Sufyān $\rightarrow$ al-Zuhrīi: ${ }^{50}$

1a Kunnā nakrahu $\left[\text { kitābat }^{a} \text { l-ilm }^{i}\right]^{1,6}$ $[-h u]^{2,4}\left[l-k u t u b^{a}\right]^{3}\left[l-k i t a \bar{b} b^{a}\right]^{5}$

lb Hattā akraha-nā 'alay-hi [lsulțān $\left.{ }^{u}\right]^{1,3,5,6}\left[\text { l-umarä } \bar{a}^{3}\right]^{2,4}$

1c $\{$ Fa-karihna an namna'a-hu $\left.\left[\text { ahadan }^{a n}\right]^{1,6}\left[\text { l-nās } s^{a}\right]^{3,5}\right\}^{1,3,5,6}$ $\{$ Fa-lammā akrahū-nā 'alay-hi badhalnā-hu lil-nās ${ }^{i}[-y a ' n \bar{a} a l-$ hadith $\left.]^{2}\right\}^{2,4}$
We were loath of [writing down knowledge $]^{1,6}[\mathrm{it}]^{2,4}\left[\right.$ books] ${ }^{3}[\text { al-kitā } b]^{5}$ Until [the authority] 1, 3, 5, 6 [the rulers] ${ }^{2,4}$ forced us to [accept] it

\{And therefore we became loath to prevent it from [anyone] $]^{1,6}$ [the people] $\left.{ }^{3,5}\right\}^{1,3,5,6}$ \{And when they forced us to do so, we readily gave it to the people [-that is, Tradition $\left.]^{2}\right\}^{2,4}$

Although Sufyān b. 'Uyayna is an apparent point of convergence of multiple transmissions (see the right section of Fig. 5.1), the actual evidence that may shed light on his role as a possible CL of the coercion tradition is limited to the traditions of al-Dārimī and Ibn Abī Khaythama. Let us now compare the mutūn in an attempt to reconstruct the hypothetical base version.

Sub-clause 1a. Except for the predicate kunnā nakrahu, al-Zuhrì's statement is markedly different in its later transmissions. According to the most remarkable variant, cited by al-Dārimī, al-Zuhrī used the expression kitäbat ${ }^{u} l^{-}$- $l m^{i}$. One can hardly doubt that the mașdar "kitābatun" is a lectio facilior that was meant to evade the conceptual ambiguity and theological embarrassment caused by the word kitāb $b^{u n}$. Even though the clause nakrahu l-kitäbat ${ }^{a}$ would have been sufficient to aver that al-Zuhri was "loath of writing," the conjunction of kitābat ${ }^{u n}$ in an iẹa fa compound with the word 'ilm in al-Dārimī's transmission betrays eagerness to avoid at all costs the scriptural undertone of subclause 1a. The criterion of conceptual transparency suggests that al-Dārimì's

47 Abū Nu'aym al-Iṣbahānī, Hilyat al-awliyā’ wa-țabaqāt al-așfiy $\bar{a}^{3}, 10$ vols. (Cairo: Maktabat al-Khanjī, 1932-1938; reprint, Beirut: Dār al-Fikr, 1416/1996), 3:363.

48 Ibn 'Abd al-Barr, Jāmic', 1:636, no. 1096.

49 al-Dhahabī, Tārîkh al-islām, ed. 'Umar Tadmurī, 53 vols. (Beirut: Dār al-Kitāb al-'arabī, 1409-/1989-), 8:240.

50 Ibn Ḥajar, Ithāaf al-mahara bi-l-fawā̉id al-mubtakara min ațrāf al-'ashra, ed. Zuhayr alNāṣir, 19 vols., 1st ed. (Medina: Wizārat al-Shu'ūn al-islāmiyya, 1415/1994), 19:485, no. 25271. 
peculiar formulation was brought into existence by a redactional improvement that postdates 'Abd al-Razzāq's tradition that came to our attention in the previous section. It should be recalled that 'Abd al-Razzāq preserved the older form kitā $b^{u n}$, which al-Dārimī, or his informant, transformed to kit$\bar{a} b a t^{u n}$.

Ibn Abī Khaythama's statement, nakrahu-hu (we were loath of it), is an undoubtedly secondary reading of sub-clause $1 \mathrm{a}$, in which the accusative pronoun - $h u$ was substituted for the word kitāb, found in the other traditions. This emendation, which blurs the direct object, is indicative of the Muslim traditionists' wariness of using the word kitāb in a markedly negative conjunction with the verb kariha.

Abū Nu'aym, who in all other respects agrees with al-Dārimī, cites the plural form kutub, thereby conveying the notion of multiple writings instead of a singular (sacred) writ. The anaphoric referent - $h u$ (sing., masc.) in the next two sub-clauses of Abū Nu'aym's tradition indicates that the form kutub, which requires - $h \bar{a}$ as a pronominal referent, is most likely an error. Even so, it exposes the high degree of exegetical discomfiture caused by the occurrence of the word kitāb in sub-clause 1 .

Al-Dhahabì's variant matn stands out from the others in that it includes the word kitāb without qualifications, and that al-Dhahabī (d. 748/1348) omits all transmitters between himself and Ibn 'Uyayna (d. 198/813), who died $55^{\circ}$ lunar years earlier. An important clue about al-Dhahabì's source crops up as soon as we take into account the almost complete agreement of sub-clauses $1 \mathrm{~b}$ and $1 \mathrm{c}$ in his tradition with al-Dārimì's respective sub-clauses. Nevertheless, this is not the whole story, as al-Dhahabi's variant sub-clause 1a is identical to sub-clause 1a in al-Fasawì's tradition studied in sub-section 'Abd al-Razzāq al-Șan'ānī. Unlike the other transmissions through Ibn 'Uyayna, in which we came across secondary variants of sub-clause 1a, al-Dhahabì cites the earliest formulation of the same sub-clause. He may have suspended the isnād in the above-described manner because he considered Ibn 'Uyayna as the most important transmitter of the bundle, who used the word kitāb without additional qualifications.

Sub-clause ıb. Al-Dārimī $\rightarrow$ Ibn 'Uyayna transmits, hattā akraha-nā 'alay-hi lsulțān $n^{u}$ (until the authority forced us to [accept] it), which is almost identical to sub-clause $1 \mathrm{~b}$ in al-Fasawī $\rightarrow$ 'Abd al-Razzāq (hattā akraha-nā 'alay-hi l-umarä $\bar{a}^{\jmath}$ : until the rulers forced us to [accept] it). Ibn Abī Khaythama $\rightarrow$ Ibn 'Uyayna agrees with al-Fasawī $\rightarrow$ 'Abd al-Razzāq verbatim. These similarities may be pointing to a shared source that predates 'Abd al-Razzāq and Ibn 'Uyayna, just as they may be signaling textual interplay, at various stages of transmission, between the traditions al-Fasawī and al-Dārimī/Ibn Abī Khaythama transmit 
on the authority of 'Abd al-Razzāq and Ibn 'Uyayna. Al-Dārimī's peculiar reference to the rulers who forced al-Zuhrī to record traditions as sulțān (authority) allows for the possibility that the old tradition, as cited by al-Fasawi through 'Abd al-Razzāq, was ascribed to Ibn 'Uyayna. It should be recalled that al-Dārimì's sub-clause 1a bears the signs of later editing with the aim of suppressing the scriptural connotation of the word kitāb. To camouflage his altering of that sub-clause, the redactor presumably substituted sultān for $u m a r a \bar{a}$ ' and launched through Ibn 'Uyayna a dive ${ }^{51}$ over the tradition's most salient transmitter, 'Abd al-Razzāq. Al-Dārimī's informant, Bishr b. al-Ḥakam al-Naysābūrī, is known to have transmitted profusely and perhaps too liberally on the authority of Ibn 'Uyayna (rawā 'an Ibn Uyayna fa-akthara). ${ }^{52}$ Hence, he may be held responsible for altering the matn and reassigning the isnād. Ibn Abī Khaythama's informant, 'Abd al-Raḥmān b. Yūnus is, as it were, Bishr b. al-Hakam's spitting image. Employed by Ibn 'Uyayna as a mustamlī (that is, repetitor who recites aloud his master's traditions before large audiences), ${ }^{53}$ 'Abd al-Raḥmān may have associated with him every kind of traditions.

Sub-clause 1c. Al-Dārimī, and Ibn Hajar on the authority of al-Dārimī, have fa-karihna an namna'a-hu ahad ${ }^{a n}$ (and we became loath to prevent it from anyone), whereas Abū Nu'aym (d. 430/1038) and al-Dhahabī (d. 748/1348) have fa-karihnā an namna'a-hu l-nās ${ }^{a}$ (and we became loath to prevent it from the people). The exact source of the latter expression is impossible to pinpoint, but, conceivably, it postdates al-Dārimì. Our text-critical survey in sub-section 'Abdal-Razzāqal-San'āni already suggested, tentatively, that the generic $a h a d^{a n}$ represents the oldest formulation in sub-clause ic. Now, al-Dārimī's tradition provides concrete evidence to shore up this hypothesis. The criterion of conceptual transparency suggests that al-nās in the traditions of Abū Nu'aym and al-Dhahabì through Ibn 'Uyayna was a secondary specifying variant of the original $\mathrm{ahad}^{a n}$, still vague and, therefore, presumably earlier than the definite muslim $^{a n}$ in al-Fasawìs transmission through 'Abd al-Razzāq.

Compared to al-Dārimī's sub-clause 1c, Ibn Abī Khaythama's variant of the same sub-clause is longer and more fictionalised, which allows us to consider it

$5^{1}$ "Dive" is a term coined by Gautier H.A. Juynboll to designate a fictitious single-strand isnād that bypasses a key transmitter or the CL in an isnād line to a transmitter situated at various removes below their level (for a detailed explanation, see Juynboll, Encyclopedia, xxiixxiii).

$5^{2}$ Ibn Ḥajar, Tahdhīb, 1:448.

53 al-Mizzī, Tahdhīb, 18:23. 
later than al-Dārimī's variant. Notwithstanding some superficial resemblances (the verb mana'a in Ibn Abī Khaythama's transmission and the same verb together with $a$ a $\mathrm{d}^{\text {un }}$ in al-Dārimì's transmission), neither of the two variants resembles sub-clause $1 \mathrm{c}$ in al-Fasawì's or 'Abd al-Razzāq's tradition.

The matn evidence in the present cluster suggests two conclusions.

First, al-Dārimī and Ibn Abī Khaythama transmit sub-clauses ıa and ıb that agree in a way suggesting the existence of a shared source. Since this agreement extends to the corresponding clauses in al-Fasawī $\rightarrow$ 'Abd al-Razzāq, which preserve the oldest formulations, especially in sub-clause 1a, al-Fasawi's contemporaries al-Dārimī and Ibn Abī Khaythama may have based their variants on his tradition. At the same time, I cannot rule out the possibility that they transmitted an old source tradition independently from al-Fasawi and 'Abd alRazzāq. It is impossible to identify Sufyān b. 'Uyayna as a transmitter of this hypothetical tradition, because all collectors above his level rely on singlestrand asānìd, that is, to use Juynboll's terminology, we are dealing with a suspicious "spider."54 The two earliest collectors above the level of Sufyān, alDārimì and Ibn Abī Khaythama, cite informants mostly known for their fondness of Ibn 'Uyayna's traditions. Such biographical data is equivocal: insofar as Ibn 'Uyayna (d. 198/713) supposedly attended al-Zuhrī's (d. 124/742) lessons, he would have held much allure for seekers of elevated asānìd through alZuhrī.

Second, sub-clause $1 c$ in the transmissions of al-Dārimī and Ibn Abī Khaythama differs considerably from sub-clause $1 c$ in the transmissions of 'Abd alRazzāq and al-Fasawì. Taking into account the overall agreement of sub-clauses $1 \mathrm{a}$ and $\mathrm{lb}$ across all variant traditions, I suspect that we are dealing with a compound narrative including an old textually fixed part (sub-clauses $1 \mathrm{a}$ and $1 \mathrm{~b}$ ) and a supplementary textually fluid part (sub-clause ic).

\subsubsection{Al-Fasawī}

In an isolated tradition through the interrupted single-strand isnād Ibrāhìm b. al-Mundhir (d. 236/850-851) $\rightarrow$ al-Zuhrī (d. 124/742) (see the left section of Fig. 5.1), al-Fasawī has:

(1a) Kunnā lā narā l-kitāb $b^{a}$ shay'an (1b) fa-akrahat-nā 'alay-hi l-umaräa (1c) fa-aḥbabnā an nuwāsiya bayn ${ }^{a} l-n \bar{a} s^{i}$. 
(1a) We used to regard al-kitāb as naught (1b) but the rulers forced us to [accept] it (1c) and therefore we preferred to treat the people as equals. ${ }^{55}$

Let us compare al-Fasawì's matn with the mutūn that we studied to this point, and especially with al-Fasawì's tradition on the authority of 'Abd al-Razzāq (see sub-section 'Abd al-Razzāq al-San'ānī).

Sub-clause 1a. In al-Fasawì's isolated tradition through Ibrāhīm b. al-Mundhir, this sub-clause is markedly different from sub-clause 1a in al-Fasawi $\rightarrow$ 'Abd al-Razzāq. As the latter is similar to sub-clause 1a in the other traditions through 'Abd al-Razzāq and in those through Ibn 'Uyayna, the criterion of frequency of use suggests that sub-clause 1a in the transmission al-Fasawī $\rightarrow$ 'Abd al-Razzāq stands closer to the original shared narrative than does the peculiar formulation in al-Fasawī $\rightarrow$ Ibrāhīm $b$. al-Mundhir. It will be remembered also that the statement lā narā l-kitāb $b^{a}$ shay'an (we used to regard al-kitāb as naught) bears the signs of an emotional coloring, which points to it being a later fictionalised variant of the matter-of-fact statement kunnā nakrahu l-kitāb $b^{a}$ in the transmission al-Fasawī $\rightarrow$ 'Abd al-Razzāq. It is nevertheless remarkable that, despite the differences, sub-clause 1a in al-Fasawìs isolated tradition preserves the unqualified use of the word kitāb. Thus, it agrees with al-Fasawì's variant on the authority of 'Abd al-Razzāq (see sub-section 'Abd al-Razzāq al-Șan'ānī) and brings to mind al-Dhahabï's variant on the authority of Ibn 'Uyayna (see subsection Sufyān b. 'Uyayna). Recall that in the latter two cases, we concluded that the specific use of al-kitāb refers to a formulation pre-dating 'Abd al-Razzāq and Ibn 'Uyayna and points to an obscure Sitz im Leben other than the hitherto presumed controversy over the ways of transmitting knowledge at the beginning of the second century AH/eighth century CE.

Sub-clause $1 b$. Al-Fasawì's isolated tradition is similar to the transmissions through 'Abd al-Razzāq and Ibn 'Uyayna. We may think, therefore, that alFasawi's formulation goes back to the oldest narrative core of the coercion tradition.

Sub-clause $1 c$. In al-Fasawi's isolated tradition, this sub-clause strikes one with its use of the verb nuwāsi, by which it states the necessity of treating all Muslims as equals. Thus, it articulates what the other traditions only intimate: Tradition is the common property of all Muslims, and no one should be exempted from its knowledge. The criterion of conceptual transparency suggests that this unambiguous formulation postdates traditions that only hint at equality between Muslims. In any case, the equalitarian concern in sub-clause ic sets 
it clearly apart from sub-clauses $1 \mathrm{a}$ and $\mathrm{ib}$ with their scriptural concern. Once again, we may conclude that the coercion tradition is a compound narrative, which has absorbed sub-clause ic at a late stage of its textual development.

\section{4}

\section{Summary and Conclusion}

Had Gautier H.A. Juynboll studied the present isnād bundle (see Fig. 5.1), he most likely would have questioned al-Zuhri's role as the possible CL of the coercion tradition. Juynboll would have based this skeptical opinion on two main arguments. First, the asānìd above al-Zuhrìs level are unverifiable single strands; second, Sufyān b. 'Uyayna, who cannot have met al-Zuhrī due to the large age difference between the two, is a seeming PCL inserted by a later collector, perhaps al-Dārimī, as a dive over the actual CL of the tradition. This CL is 'Abd al-Razzāq al-Ṣan'ānī, whose collection of traditions is extant and thus represents the earliest source to include the coercion tradition. ${ }^{56}$ Since this tradition is neither a legal maxim nor qașaș, it cannot be dated before the floruit of the CL. The ensuing chronology of the said tradition would be no earlier than the second half of the second century AH.

Our delving into the isnād evidence can add little to Juynboll's supposed conclusions. The asānìd that pass through Ibn 'Uyayna are anomalous: they use technical terminology that puts the historicity of his transmission from alZuhrī under serious doubt, they lack Meccans transmitting on the authority of the Meccan Ibn 'Uyayna, and they carry mutūn that fall foul of Ibn 'Uyayna's oralist attitude to hadith transmission. 'Abd al-Razzāq's isnād through Ma'mar b. Rāshid $\rightarrow$ al-Zuhrī may be either authentic or forged, but, in the absence of PCLs above Ma'mar's level, there is no way to verify these possibilities. AlFasawī's single-strand isnād through Ibrāhīm b. al-Mundhir $\rightarrow$ al-Zuhrī does not inspire confidence owing to the large temporal gap between the latter two transmitters. Arguably, Ibrāhīm may have availed himself of a written source, perhaps a copy of Mūsā b. 'Uqba's biography of the Prophet, in which he reported profusely on al-Zuhri's authority, but, owing to its subject matter, this work may hardly have included a tradition treating al-Zuhrîs relationship with the Umayyad rulers.

Thus, we reach the limits of formal isnād analysis: 'Abd al-Razzāq is the CL of the coercion tradition, which he may have forged (for what reason?) or received

56 For a similar line of reasoning with respect to a transmission of Macmar b. Rāshid and Sufyān b. 'Uyayna on the authority of al-Zuhrī, see Juynboll, "Some Notes," 302-304. 
from an earlier source (but how to identify it?). The isnād constraints notwithstanding, the matn offers a promising path into the history of the tradition below the CL level. I have shown that whereas 'Abd al-Razzāq used the expression kunnā nakrahu kitāab al-ilm (we were loath of writing down knowledge), in its earliest form, preserved by al-Fasawī, the matn included the phrase kunna $\bar{a}$ nakrahu l-kitā $b^{a}$, which apparently implies loathness of scripture. This recondite expression baffled later transmitters, who tried to suppress its scriptural connotation by placing kitāb in an id äfa compound with the word 'ilm or by dropping kitāb from the matn altogether. I will address the Sitz im Leben of the scriptural loathness in a forthcoming publication. ${ }^{57}$ For our current purposes, it is sufficient to say that this concern pre-dates the CL, that is, it most likely belongs in the first half of the second century AH/eighth century CE.

An important hint at the tradition's history is its composite structure, signaled by two matn features. First, sub-clauses $1 \mathrm{a}$ and $1 \mathrm{~b}$ give expression to a scriptural concern, whereas sub-clause ic reveals an equalitarian concern. Second, across the transmissions included in Fig. 5.1, sub-clauses 1a and $1 \mathrm{~b}$ are textually more stable than sub-clause ic. Thus, it seems, the former sub-clauses represent the tradition's ancient core to which sub-clause 1c was subsequently added. The compound narrative was put into circulation by 'Abd al-Razzāq or Ibrāhīm b. al-Mundhir, or by one of their direct informants. Sub-clauses 1a and $1 \mathrm{~b}$, however, must have existed before these compilers' floruit. Our current study cannot provide sufficient evidence for associating the coercion tradition with al-Zuhrī, but future analysis of its semantic structure and inherent concerns may well indicate that this was the case, at least with regard to sub-clauses $1 \mathrm{a}$ and $\mathrm{ib}$.

\section{Acknowledgements}

I would like to thank Professor Harald Motzki and Professor Gregor Schoeler for their comments on an early draft of this essay. I am indebted to the editors of this volume for their critical suggestions, which allowed me to improve the quality of my exposition. All errors of fact and judgement are the author's sole responsibility.

57 Pavel Pavlovitch, "Kunnā Nakrahu al-Kitāb: Scripture, Transmission of Knowledge, and Politics in the Second Century AH (719-816 CE)," forthcoming in a volume from the symposium "Modern Hadith Studies between Arabophone and Western Scholarship," Pembroke College, University of Oxford, o9-10.01.2017. 


\section{Bibliography}

Abbott, Nabia. Studies in Arabic Literary Papyri. Volume 2. Qur'ānic Commentary and Tradition. Chicago: The University of Chicago Press, 1967.

'Abd al-Razzāq al-Ṣanānī. Muṣannaf. Edited by Ḥabīb al-Raḥmān al-A'ẓamī. 12 vols. 2nd edition. Beirut: al-Maktab al-islāmī, 1403/1983.

Abū Nu'aym al-Iṣbahānī. Hilyat al-awliyā’ wa-țabaqātal-aşfyā̄. 10 vols. Cairo: Maktabat al-Khanjī, 1932-1938. Reprint, Beirut: Dār al-Fikr, 1416/1996.

al-Balādhurī. Ansāb al-ashrāf. Edited by Suhayl Zakkār and Riyāḍ Zarkalī. 13 vols. 1st edition. Beirut: Dār al-Fikr, 1417/1996.

al-Bayhaqī. al-Madkhal ilā al-Sunan al-kubrā. Edited by Muhammad al-A`ẓamī. 2 vols. 2nd edition. Riyadh: Aḍwā’ al-salaf, 1420.

Cook, Michael. "The Opponents of the Writing of Tradition in Early Islam." Arabica 44, no. 4 (1997): 437-530.

al-Dārimī. Sunan. Edited by Ḥusayn al-Dārānī. 4 vols. 1st edition. Riyadh: Dār al-Mughnī, 1421/200o.

al-Dhahabī. Siyar a 'ām al-nubalā'. Edited by Shu'ayb al-Arna’ūṭ. 39 vols. Beirut: Mu’assasat al-Risāla, 1401-1417/1981-96.

al-Dhahabī. Țabaqāt al-huffāz. 1st edition. Beirut: Dār al-Kutub al-ilmiyya, 1403/1983.

al-Dhahabī. Tārīkh al-islām. Edited by 'Umar Tadmurī. 53 vols. Beirut: Dār al-Kitāb al'arabī, 1409-/1989-.

Ess, Josef van. Zwischen Hadīt und Theologie: Studien zum Entstehen prädestinatianischer Überlieferung. Berlin: Walter De Gruyter, 1975.

al-Fasawī. al-Ma'rifa wa-l-tārīkh. Edited by Akram al-'Umarī. 4 vols. 1st edition. Medina: Maktabat al-Dār, 1410.

Gledhill, Paul. "Motzki's Forger: The Corpus of the Follower 'Ațā' in Two Early 3rd/9thCentury Hadīth Compendia." Islamic Law and Society 19, no. 1-2 (2012): 16o-193.

Goldziher, Ignaz. Muhammedanische Studien. Zweiter Theil. Halle a. S.: Max Niemeyer, 1890.

Goldziher, Ignaz. Muslim Studies. Volume 2. Translated by C.R. Barber and S.M. Stern. London: George Allen \& Unwin Ltd, 1971.

Görke, Andreas. "Eschatology, History, and the Common Link: A Study in Methodology." In Method and Theory in the Study of Islamic Origins, edited by Herbert Berg, 179-208. Leiden: Brill, 2003.

al-Ḥākim al-Naysābūrī. al-Madkhal ilā ma'rifat Kitāb al-Iklīl. Edited by Aḥmad al-Sallūm. Beirut: Dār Ibn Hazm, 1423/2003.

Ibn 'Abd al-Barr. Jāmi' bayān al-'ilm wa-fạ̣ li-hi. Edited by Abū al-Ashbāl al-Zuhayrī. 2 vols. 1st edition. Dammam: Dār Ibn al-Jawzī, 1994.

Ibn Abī Ḥātim al-Rāzì. al-Jarḥ wa-l-ta'dīl. 9 vols. Beirut: Dār Ihyā̄ al-turāth al-ārabī, n.d. Ibn Abī Khaythama. al-Tārīkh al-kabìr. Edited by Ṣalāh Halal. 4 vols. ıst edition. Cairo: al-Farūq al-ḥadītha, 1424/2004. 
Ibn 'Asākir. Tārīkh madīnat Dimashq. Edited by 'Umar al-Amrawī. 8o vols. Beirut: Dār al-Fikr, 1415-1421/1995-200o.

Ibn Hajar. Ithāff al-mahara bi-l-fawāंid al-mubtakara min ațrāf al-'ashra. Edited by Zuhayr al-Nāṣir. 19 vols. 1st edition. Medina: Wizārat al-Shu'ūn al-islāmiyya, 1415/ 1994.

Ibn Hajar. Tahdhīb al-Tahdhīb. 12 vols. Hyderabad, 1325.

Ibn Ḥibbān. Kitāb al-Thiqāt. Edited by Muḥammad 'Abd al-Mu'īd Khān. 10 vols. Mu’assasat al-Kutub al-thaqafiyya, 1973/1393.

Ibn Kathīr. al-Bidāya wa-l-nihāya. Edited by 'Abdallāh al-Turkī. 21 vols. 1st edition. Cairo: Dār Hajar, 1417-1420/1997-1999.

Ibn Sa'd. al-Ṭabaqāt al-kubrā. Edited by 'Alī 'Umayr. 11 vols. 1st edition. Cairo: Maktabat al-Khanjī, 1421/2001.

Juynboll, Gautier H.A. "Early Islamic Society as Reflected in Its Use of Isnāds." Le Museon 107 (1994): 151-194.

Juynboll, Gautier H.A. Encyclopedia of Canonical Hadīth. Leiden: Brill, 2007.

Juynboll, Gautier H.A. “Muslim b. al-Ḥadjdjādj.” In Encyclopaedia of Islam, 2nd edition. Accessed 13 August 2018. http://dx.doi.org/10.1163/1573-3912_islam_SIM_5597.

Juynboll, Gautier H.A. Muslim Tradition: Studies in Chronology, Provenance and Authorship of Early hadìth. Cambridge: Cambridge University Press, 1983.

Juynboll, Gautier H.A. "Nāfi', the mawlā of Ibn 'Umar, and his Position in Muslim Hadīth Literature." Der Islam 70, no. 2 (1993): 207-244.

Juynboll, Gautier H.A. "New Perspectives in the Study of Early Islamic Jurisprudence." Bibliotheca Orientalis 49, no. 3-4 (1992): 357-364.

Juynboll, Gautier H.A. “Some Notes on Islam's First Fuqahä’ Distilled from Early Hadīt Literature." Arabica 39, no. 3 (1992): 287-314.

al-Khațīb al-Baghdādī. Taqyīd al-'ilm. Edited by Yūsuf al-'Ishsh. Damascus: al-Ma'had al-faransī bi-Dimashq, 1949 .

al-Khațīb al-Baghdādī. Tārīkh Baghdād. Edited by Bashshār Ma'rūf. 17 vols. Beirut: Dār al-Gharb al-islāmī, 1422/2001.

Kister, Meir J. “... Lā taqra'ū l-qurāana 'alā l-mușhafiyyīna wa-lā taḥmilū l-ilma 'ani lșahafiyyīn ... Some Notes on the Transmission of Hadìth." Jerusalem Studies in Arabic and Islam 22 (1998): 127-162.

Lecker, Michael. "Biographical Notes on Ibn Shihāb al-Zuhrī.” Journal of Semitic Studies 41, no. 1 (1996): 21-63.

al-Mizzī. Tahdhīb al-Kamāl fĩ asmāà al-rijāl. Edited by Bashshār Ma'rūf. 35 vols. 2nd edition. Beirut: Mu’assasat al-Risāla, 1983/1403.

Motzki, Harald. "Dating Muslim Traditions: A Survey." Arabica 52, no. 2 (2005): 204-253.

Motzki, Harald. The Origins of Islamic Jurisprudence: Meccan Figh before the Classical Schools. Translated by Marion H. Katz. Leiden: Brill, 2002.

Nagel, Tilman. "Hadīt-oder: Die Vernichtung der Geschichte." In XXV. Deutscher Orient- 
alistentag, Vorträge, München 8.-13.4.1991, edited by Cornelia Wunsch, 118-128. ZD MG Supplement 10. Stuttgart: Franz Steiner, 1994.

Pavlovitch, Pavel "Kunnā Nakrahu al-Kitāb: Scripture, Transmission of Knowledge, and Politics in the Second Century AH (719-816 CE)." Forthcoming in a volume from the symposium "Modern Hadith Studies between Arabophone and Western Scholarship," Pembroke College, University of Oxford, o9-10.01.2017.

Pavlovitch, Pavel. The Formation of the Islamic Understanding of Kalāla in the Second Century AH (718-816 CE): Between Scripture and Canon. Leiden: Brill, 2016.

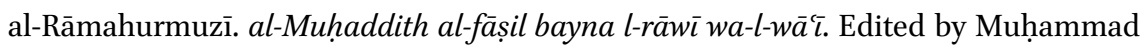
al-Khațīb. 1st edition. Beirut: Dār al-Fikr, 1391/1971.

Schoeler, Gregor. Charakter und Authentie der muslimischen Überlieferung über das Leben Mohammeds. Berlin: Walter De Gruyter, 1996.

Schoeler, Gregor. "Oral Torah and Hadīt: Transmission, Prohibition of Writing, Redaction." In The Oral and Written in Early Islam. Edited by James E. Montgomery. Translated by Uwe Vagelpohl, 111-141. London: Routledge, 2006.

Schacht, Joseph. Origins of Muhammadan Jurisprudence. Oxford: Clarendon Press, 1950.

Sezgin, Fuat. Geschichte des Arabischen Schrifttums (GAS). Band 1: Qurānwissenschaften, Hadiut, Geschichte, Fiqh, Dogmatik, Mystik, bis ca. 430 H. Leiden: Brill, 1967.

Sprenger, Aloys. "On the Origin and Progress of Writing down Historical Facts among the Musalmans." Journal of the Asiatic Society of Bengal 25, no. 4 (1856): 303-329.

Zaman, Iftikhar. "The Evolution of a Hadith: Transmission, Growth and the Science of Rijal in a Hadith of Sa'd B. Abī Waqqas." PhD diss., University of Chicago, 1989. 